\title{
KAJIAN PENATAAN RUANG DAN PENGGUNAAN MATERIAL PADA BANGUNAN PENGASAPAN IKAN (STUDI KASUS: SENTRA PENGASAPAN IKAN BANDARHARJO)
}

\author{
Dhony Setyawan, Hermin Werdiningsih*) \\ *)Departemen Arsitektur, Fakultas Teknik, Universitas Diponegoro
}

\begin{abstract}
Bangunan pengasapan ikan merupakan salah satu bangunan industri rumah tangga yang banyak terdapat di Indonesia, salah satunya di Semarang. Di Semarang sendiri bangunan pengasapan ikan berada di kawasan sentra pengasapan ikan di Bandarharjo, Semarang Utara. Pada kawasan sentra pengasapan ikan Bandarharjo, terdapat kuranglebih 35 bangunan pengasapan ikan yang aktif melakukan kegiatan produksi ikan asap setiap harinya. Pembahasan mengenai bangunan pengasapan ikan ini akan difokuskan ke arah penataan ruang dan penggunaan material pada bangunan pengasapan ikan yang terdapat di sentra pengasapan ikan Bandarharjo. Mayoritas bangunan pengasapan ikan di sentra pengasapan ikan Bandarharjo menggunakan kayu dan bambu sebagai material utama bangunan.Untuk material lain yang digunakan adalah seng, GRC board dan plesteran yang diaplikasikan pada bagian dinding dan lantai bangunan pengasapan ikan. Sedangkan untuk tata ruang pada bangunan pengasapan ikan cukuplah sederhana, dimana tata ruang yang ada menyesuaikan alur proses yang terdapat dalam kegiatan produksi ikan asap. Melalui pengkajian mengenai penataan ruang dan penggunaan material pada bangunan pengasapan ikan ini didapatkan bahwasannya ada beberapa hal yang masih kurang dalam penataan ruang dan penggunaan material bangunan. Perlu ditingkatkannya kesadaran pelaku produksi ikan asap dan upaya dari pemerintah setempat untuk dapat bergerak bersama dalam peningkatan kualitas bangunan pengasapan ikan yang terdapat di sentra pengasapan ikan.
\end{abstract}

Keywords: bangunan; pengasapan ikan; material;

\section{PENDAHULUAN}

Pengolahan ikan asap atau sering disebut pengasapan ikan merupakan salah satu industri pengolahan ikan yang berkembang baik di Indonesia. Beberapa wilayah di pesisir pantai di Indonesia memiliki kawasan industri pengasapan ikan yang kebayakan merupakan industri rumahan, salah satunya adalah sentra pengasapan ikan Bandarharjo. Karena itu terkadang bangunan yang digunakan sebagai tempat pengasapan ikan ditata seadanya saja tanpa memikirkan penataan ruang yang baik untuk kegiatan pengolahan ikan asap tersebut. Padahal penataan ruang dalam sebuah bangunan industri cukup berpengaruh, baik terhadap pekerja industri ataupun olahan industry tersebut, termasuk pada industri pengasapan ikan. Berbagai aktivitias yang ada dalam industri tersebut harusnya digunakan sebagai dasar dalam penataan ruang pada bangunan industri, agar tercipta ruang yang baik bagi seluruh komponen yang ada.

\section{TINJAUAN PUSTAKA}

2.1. Bentuk dan Pola Permukiman Desa

2.1.1.Bentuk-bentuk Desa Menurut Daldjoeni
Menurut (Daldjoeni, 2003), bentuk-bentuk desa secara sederhana antara lain :

1.Pola permukiman menyebar (Disseminated rural settlement)

Ciri-ciri dari pola permukiman menyebar adalah jarak antara permukiman penduduk yang satu dengan yang lain terlalu jauh. Hal ini menyebabkan tipe permukiman pola menyebar tidak kondusif lagi bagi perhubungan desa dan dapat mengganggu evolusi dari desa yang baru terbentuk menjadi komunitas fungsional.

\section{Pola permukiman terpusat}

Ciri-ciri pola permukiman terpusat adalah: a. Plot rumah saling berhubungan; b. Kerugiannya, yaitu jarak rumah penduduk dengan lahan pertanian mereka agak jauh; dan c. Kelebihan dari pola pemukiman terpusat, yaitu areal pertanian pribadi dapat tersebar luas.

3. Pola permukiman linier

Ciri-ciri pola permukiman linier adalah: a. Perkembangan permukiman penduduknya menurut pola jalan yang ada (memanjang atau sejajar dengan rentangan jalan raya yang menembus desa); dan b. Keuntungan dari pola 
permukiman ini adalah aksesibilitas ke kota yang tinggi.

\subsubsection{Pola Permukiman menurut Kostof}

Menurut (Kostof, 1991) dalam (Ahyat, 2013), permukiman mempunyai berbagai pola yang umum terjadi akibat berbagai faktor yang mempengaruhi, antara lain:

\section{Sub Kelompok Komunitas}

Pola permukiman tipe ini berbentuk cluster, terdiri dari beberapa unit atau kelompok unit hunian, memusat pada ruangruang penting, seperti penjemuran, ruang terbuka umum, masjid dan sebagainya (gambar 2.1)

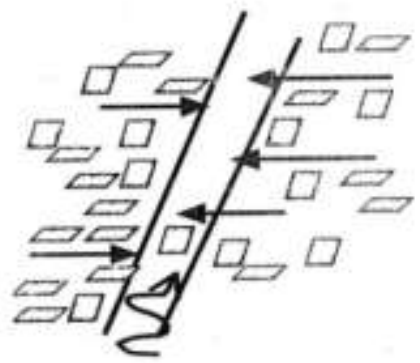

Gambar 2.1 Pola Permukiman Sub Kelompok Komunitas

\section{Face to face}

Pola permukiman tipe ini berbentuk linier, antara unit-unit hunian sepanjang permukiman dan secara linier terdapat perletakan pusat aktivitas yaitu tambatan perahu atau dermaga, ruang penjemuran, pasar dan sebagainya (gambar 2.2).

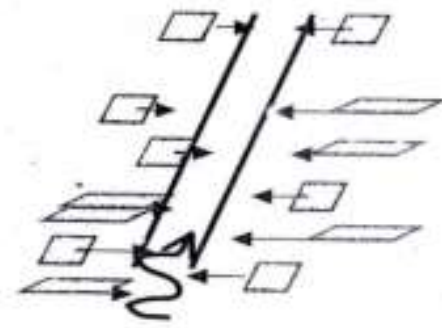

Gambar 2.2. Pola Permukiman Face to Face

\subsubsection{Struktur Ruang Permukiman : \\ 1. Linier}

Pola permukiman bentuk ini adalah suatu pola sederhana dengan peletakan unit-unit permukiman (rumah, fasum, fasos dan sebagainya) secara terus menerus pada tepi sungai dan jalan. Pada pola ini kepadatan tinggi, dan kecenderungan ekspansi permukiman dan mixed use function penggunaan lahan beragam (gambar 2.3).

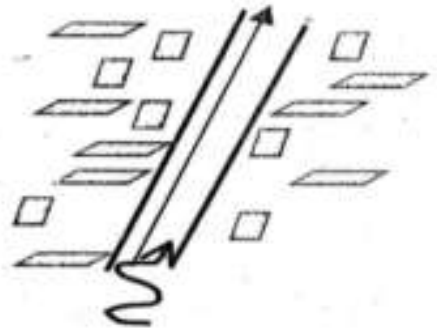

\section{Gambar 2.3. Pola Permukiman Linier}

1. Clustered

Pada pola ini berkembang dengan adanya kebutuhan lahan dan penyebaran unit-unit permukiman telah mulai timbul. Kecenderungan pola ini mengarah pada pengelompokkan unit permukiman terhadap suatu yang dianggap memiliki nilai "penting" atau pengikat kelompok seperti ruang terbuka komunal dalam melakukan aktivitas bersama (gambar 2.4).

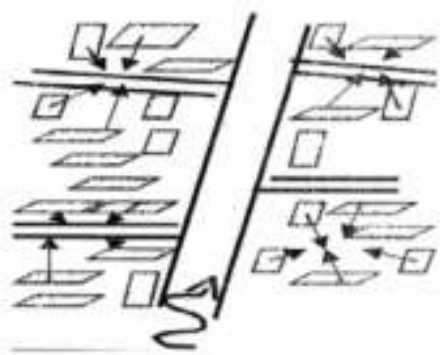

\section{Gambar 2.4 Pola Permukiman Clustered}

\section{Kombinasi}

Pola ini merupakan kombinasi antara kedua pola di atas yang menunjukkan bahwa selain ada pertumbuhan juga menggambarkan adanya ekspansi ruang untuk kepentingan lain (pengembangan usaha dan sebagainya). Pola ini menunjukkan adanya gradasi dari intensitas lahan dan hirarki ruang mikro secara umum (gambar 2.5)

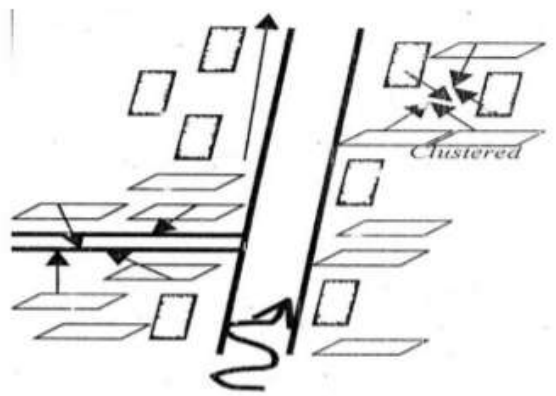

Gambar 2.5 Pola Permukiman Kombinasi

\subsection{Tinjauan Umum Sentra Pengasapan Ikan}

2.2.1.Pengertian Sentra Pengasapan Ikan

Merupakan pusat kawasan/tempat kegiatan yang berhubugan dengan kegiatan proses pengasapan ikan 
dan kegiatan pendukung lainnya yang berhubungan dengan proses pengasapan ikan.

\subsubsection{Fungsi Sentra Pengasapan Ikan}

Fungsi Sentra Pengasapan Ikan sebagai pusat kegiatan untuk kegiatan industri pengasapan dan kegiatan penjualan ikan asap sebagai hasil produksi dari industri pengasapan.

\subsubsection{Aktivitas dalam Sentra Pengasapan Ikan}

Aktivitas yang ada pada sentra pengasapan ikan dapat dikelompokkan berdasar suhu pengasapan, yaitu :

a. Pengasapan dingin

b. Pengasapan panas

c. Pengasapan Elektrik

d. Pengasapan Likuid

Dalam proses pengasapan panas terdiri dari proses :

a. Pengelompokkan, Penyiangan, dan Pencucian Ikan

b. Pemotongan Ikan

c. Penggaraman

d. Pengeringan

e. Pengasapan

f. Pendinginan dan Pengemasan

2.2.4. Persyaratan Sentra Pengasapan Ikan ikan, yaitu :

Persyaratan untuk mendirikan sentra pengasapan

a. Sentra pengasapan ikan harus mampu mengakomodir kegiatannya baik kegiatan industri maupun kegiatan komersial, melalui :

a. Syarat ketinggian minimum cerobong 2-2,5 kali tinggi bangunan disekitarnya, serta pada bagian dalam cerobong terdapat filter untuk menyaring asap.

b. Air yang digunakan dalam proses produksi ikan asap harus berasal dari sumber air yang telah memenuhi persyaratan sebagai air layak minum.

c. Harus terdapat tempat untuk penyimpanan khusus untuk alat yang digunakan dalam produksi ikan.

d. Bahan yang digunakan pada lantai, meja, dan alat pengasapan harus merupakan bahan yang mudah untuk dibersihkan.

e. Setiap area pemotongan, pencucian, pengasapan, penyimpanan harus dapat dibedakan dan terpisah, tetapi harus saling berhubungan.

f. Bahan utama dari bangunan pengasapan harus menggunakan bahan yang memenuhi persyaratan arsitektural bangunan industri. Berikut merupakan tabel material dan kondisi elemen ruang pada industri pangan.

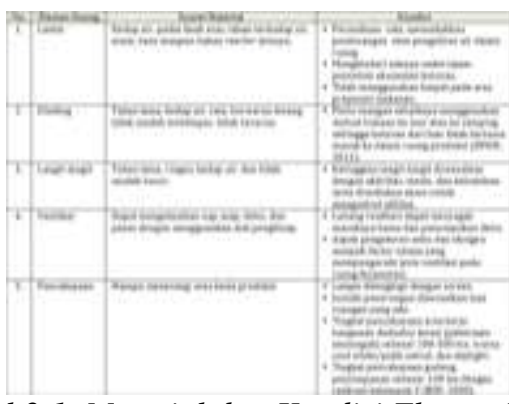

Tabel 2.1. Material dan Kondisi Elemen Ruang pada Industri Pangan (Rahayu, et al., 2015)

g. Harus terdapat fasilitas untuk penyimpanan dan pendinginan bahan baku ikan.

h. Pada bagian pengasapan terdapat tungku yang terhubung dengan cerobong.

i. Ventilasi udara pada tungku pengasapan harus hampur tertutup.

j. Tempat pengeringan ikan harus memiliki tingkat kelembaban yang lebih rendah dari tingkat kelembaban di ruangan pengasapan.

k. Harus terdapat fasilitas drainase yang memadai, harus terdapat fasilitas pengolahan limbah(IPAL).

1. Terdapat fasilitas sanitasi yang memadai untuk pekerja.

\section{METODE PENELITIAN}

Penelitian dilakukan di Sentra Pengasapan Ikan Bandarharjo yang bertempat di Kelurahan Bandarharjo, Semarang Utara pada bulan September-Oktober 2015 dan Oktober 2016. Pendekatan penelitian menggunakan metode survey (pengumpulan data), wawancara, foto dan study literature secara kualitatif dengan analisa induktif.

\section{DATA DAN ANALISA}

4.1. Bentuk dan pola sentra pengasapan ikan bandarharjo

Berdasarkan teori yang dikemukakan (Daldjoeni, 2003), bentuk dari sentra pengasapan ikan Bandarharjo termasuk dalam pola permukiman linier karena perkembangan yang terjadi pada sentra pengasapan ikan bandarharjo menurut pola jalan yang ada (memanjang atau sejajar dengan rentangan jalan raya yang menembus desa).

Berdasarkan teori (Kostof, 1991) dalam (Ahyat, 2013), mengenai pola dan struktur ruang permukiman, sentra pengasapan ikan bandarharjo termasuk ke dalam pola dan struktur ruang permukiman Linier, karena pada Sentra pengasapan ikan Bandarharjo perletakan unit-unit rumah pengasapan ikan secara terus menerus berada pada tepi jalan. 


\subsection{Tinjauan berdasarkan standar ruang pada bangunan pengasapan ikan}

Ruang-ruang yang dibutuhkan pada bangunan pengasapan ikan sudah sesuai dengan proses yang ada pada proses pengasapan ikan. Namun masih ada beberapa hal yang kurang memenuhi standar yang ada, seperti :

$\square$ Belum ada batasan yang jelas antar ruang yang ada pada bangunan pengasapan ikan. Seharusnya jika mengacu pada standar yang ada ruang atau area yang ada haruslah dapat dibedakan dan terpisah namun tetap berhubungan.

Untuk ruang sanitasi bagi pekerja pengasapan ikan belum terdapat pada semua bangunan pengasapan ikan dan kondisinya masih terkesan seadanya (bergabung dengan area pencucian ikan).

\subsection{Tinjauan berdasarkan alur proses pengasapan ikan}

Aktivitas yang ada pada sentra pengasapan ikan Bandarharjo dalam proses pengasapan ikan adalah menggunakan proses pengasapan panas. Dimana dalam proses pengasapan panas terdapat beberapa proses yang dilakukan yakni :

a. Pengelompokkan, Penyiangan, dan Pencucian Ikan;

b. Pemotongan Ikan;

c. Penggaraman;

d. Pengeringan;

e. Pengasapan;

f. Pendinginan dan Pengemasan

Dari beberapa proses tersebut, selanjutnya dapat dikelompokkan menjadi 3 tahap pengasapan ikan, yaitu

1. Tahap Persiapan

Terdiri dari proses yang dilakukan sebelum pengasapan ikan, yaitu pengelompokan, penyiangan, pencucian, pemotongan, penggaraman dan pengeringan ikan sebelum dipanggang di atas tungku/di asap.

2. Tahap Pengasapan

Merupakan tahapan pemanggangan/pengasapan ikan di atas tungku.

3. Tahap Pengemasan

Merupakan tahap akhir dari kegiatan pengasapan ikan, dimana pada tahap ini terdapat proses pendinginan ikan yang telah selesai dipanggang/di asap untuk selanjutnya dilakukan proses pengemasan.

Jika dikaitkan dengan keruangan / lay out ruang pada bangunan pengasapan ikan, maka lay out ruang pada bangunan pengasapan ikan dapat di bagi menjadi 3 (tiga) area, yaitu area persiapan, area pengasapan dan area pengemasan. Jika di gambarkan secara sederhana, maka pembagiannya adalah sebagai berikut.

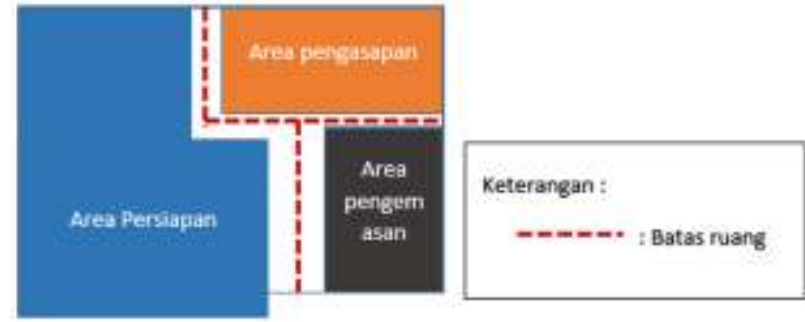

Gambar 4.1. Pembagian ruang pada bangunan pengasapan ikan (Analisa Penulis, 2016)

\subsection{Kaitan dengan lingkungan}

Lay Out ruang pada bangunan pengasapan sangat berkaitan dengan lingkungan sekitarnya, dimana jika di lihat dari sampel yang ada, letak area pencucian yang notabene merupakan tahap persiapan selalu berada di bagian depan rumah (dekat dengan akses). Hal tersebut berkaitan erat dengan arah datangnya bahan baku (ikan), dimana ketika bahan baku datang, maka dapat langsung di olah di area pencucian dan pemotongan yang berada di bagian depan bangunan pengasapan ikan. Hal tersebut tentunya untuk mempermudah dalam proses pengasapan ikan.

4.5. Tinjauan berdasarkan pendapat pelaku / pekerja pengasapan ikan

Setelah dilakukan wawancara langsung dengan pelaku / pekerja pengasapan,didapatkan beberapa temuan, yaitu :

$\square$ Pelaku / Pekerja pengasapan merasa cukup dengan ruang yang sudah ada pada bangunan pengasapan masing-masing. Dari ketua Koppin berpendapat bahwasannya benar seperti itu adanya, namun kekurangan yang ada pada bangunan pengasapan ikan yang ada di sentra pengasapan ikan Bandarharjo adalah kurang memenuhi standar pada beberapa aspek, seperti ketinggian cerobong, kebersihan ruang produksi, pengaliran air limbah cuci ikan, serta ketinggian bangunan.

Permasalahan utama yang didapatkan adalah terkait kesadaran dari pelaku / pekerja pengasapan ikan yang masih kurang. Mereka masih berpikiran simpel, yaitu dengan bekerja maka akan mendapatkan keuntungan tanpa memikirkan lebih kondisi tempat kerjanya.

\subsection{Tinjauan Material Bangunan Pengasapan Ikan}

Hasil perbandingan antara standar material bangunan pengasapan ikan dengan kondisi yang ada di lapangan adalah sebagai berikut : 
Tabel 4.1. Tabel Perbandingan Standar dan Kondisi Lapangan Material Bangunan Pengasapan Ikan

\begin{tabular}{|c|c|c|c|c|}
\hline $\mathrm{Na}$ & $\begin{array}{l}\text { Eleswem } \\
\text { Ruazz }\end{array}$ & Standar & Kondisi Lapangas & $\begin{array}{l}\text { Ketera } \\
\text { nfan }\end{array}$ \\
\hline 1 & Latail & 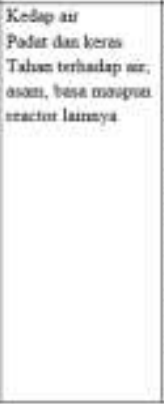 & 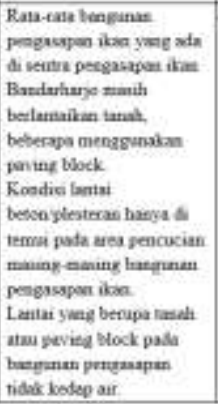 & $\begin{array}{l}\text { Tidak } \\
\text { menen } \\
\text { whi } \\
\text { standar }\end{array}$ \\
\hline 2 & Dinfeng & 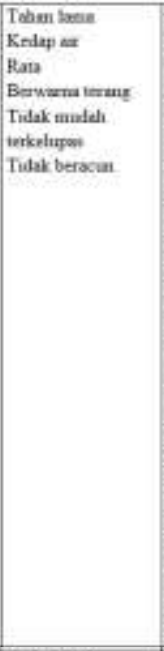 & 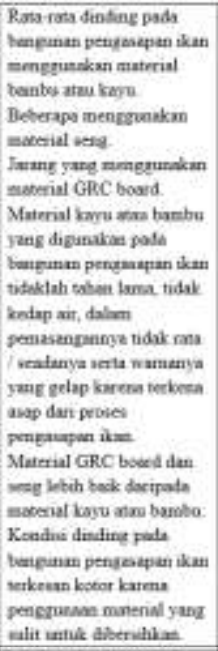 & $\begin{array}{l}\text { Thisk } \\
\text { mernes } \\
\text { uh } \\
\text { wandar }\end{array}$ \\
\hline 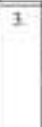 & $\begin{array}{l}\text { Langit- } \\
\text { bengit / } \\
\text { alap }\end{array}$ & 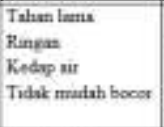 & 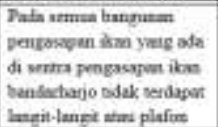 & $\begin{array}{l}\text { Thide } \\
\text { memen } \\
\text { uhi } \\
\text { standar }\end{array}$ \\
\hline 4 & Vertilian & $\begin{array}{l}\text { Daupe alat } \\
\text { pmpriasp }\end{array}$ & 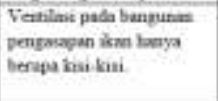 & $\begin{array}{l}\text { Tidis } \\
\text { meminn } \\
\text { uhi } \\
\text { atandr }\end{array}$ \\
\hline
\end{tabular}

Dari hasil perbandingan antara standar material bangunan pengasapan ikan dengan kondisi yang ada di lapangan didapatkan bahwasannya bangunan pengasapan ikan di sentra pengasapan ikan bandarharjo belum memenuhi standar yang ada.

Kemudian untuk mengetahui pendapat pelaku / pekerja pengasapan, dilakukan wawancara langsung terkait material bangunan pengasapan ikan yang menghasilkan beberapa temuan, yaitu :

$\square$ Meskipun belum memenuhi standar, para pelaku / pekerja pengasapan berpendapat material yang digunakan pada bangunan pengasapan saat ini tidak bermasalah.

$\square$ Para pelaku / pekerja pengasapan memilih material kayu daripada bambu, karena material kayu lebih awet.

$\square$ Sama seperti halnya mengenai keruangan dalam bangunan pengasapan ikan, kesadaran pelaku / pekerja pengasapan ikan menjadi penyebab kurang standarnya bangunan pengasapan yang mereka miliki.

$\square$ Selain karena kesadaran pelaku / pekerja pengasapan ikan, penyebab lain adalah status lahan sentra pengasapan ikan bandarharjo yang memang belum dapat di bangun bangunan pengasapan ikan yang lebih kuat dan permanen. Hal tersebut berkaitan dengan kebijakan pemerintah.

Permasalahan terakhir adalah terkait dana yang dimiliki pelaku / pekerja pengasapan ikan cukup minim.

\section{PENUTUP}

Sentra pengasapan ikan Bandarharjo termasuk ke dalam pola permukiman linier karena perkembangan yang terjadi pada sentra pengasapan ikan bandarharjo menurut pola jalan yang ada (memanjang atau sejajar dengan rentangan jalan raya yang menembus desa).

Untuk ktivitas yang ada pada sentra pengasapan ikan Bandarharjo dapat dikelompokkan menjadi 3 tahap pengasapan ikan, yaitu:

1. Tahap Persiapan Terdiri dari proses yang dilakukan sebelum pengasapan ikan, yaitu pengelompokan, penyiangan, pencucian, pemotongan, penggaraman dan pengeringan ikan sebelum dipanggang di atas tungku/di asap.

2. Tahap Pengasapan Merupakan tahapan pemanggangan /pengasapan ikan di atas tungku.

3. Tahap Pengemasan Merupakan tahap akhir dari kegiatan pengasapan ikan, dimana pada tahap ini terdapat proses pendinginan ikan yang telah selesai dipanggang/di asap untuk selanjutnya dilakukan proses pengemasan.

Kondisi sentra pengasapan ikan bandarharjo saat belum memenuhi persyaratan bagunan industri pangan, karena :

o Bahan atau material yang digunakan pada rumah pengasapan ikan terutama pada lantai dan area yang bersinggungan langsung dengan bahan baku belum memenuhi kriteria yang ada.

o Tidak terdapat batasan ruang yang jelas pada rumah pengasapan ikan, sehingga memberikan kesan seluruh ruangan yang ada menyatu dan tidak sesuai dengan sirkulasi proses pengasapan ikan.

o Tidak terdapat fasilitas pengolahan limbah (IPAL)

\section{Rekomendasi}

Terkait keruangan pada bangunan pengasapan ikan, penulis memberikan rekomendasi sederhana mengenai lay out ruang pada bangunan pengasapan ikan, yaitu : 


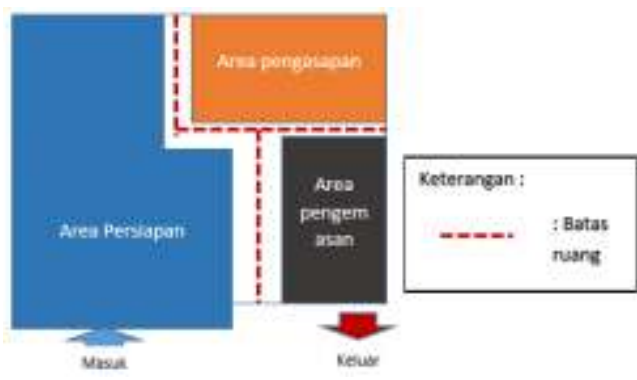

Gambar 5.2. Rekomendasi lay out ruang pada bangunan pengasapan ikan (Analisa Penulis, 2016)

Untuk lay out ruang pada bangunan pengasapan ikan secara sederhana dapat dibagi menjadi 3 (tiga) area seperti gambar di atas. Hal lain yang perlu diperhatikan adalah alur masuk dan keluarnya bahan atau hasil produksi. Ada baiknya jalur masuk dan keluarnya bahan dan hasil produksi terpisah.

Untuk batas antar ruang/area pada bangunan pengasapan ikan, seacara sederhana dapat dengan menerapkan perbadaan peil lantai antar ruang.

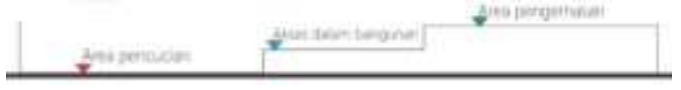

Gambar 5.3. Rekomendasi batas ruang pada bangunan pengasapan ikan (Analisa Penulis, 2016)

Dari rekomendasi di atas, dapat dilihat bahwasannya untuk area pencucian berada pada level paling rendah dan untuk area pengemasan berada pada level paling tinggi, dan untuk akses dalam bangunan berada di tengah sebagai pemisah area pencucian dan area pengemasan. Hal tersebut juga berlaku pada area pengasapan, dimana area pengasapan berada pada level di atas area pencucian namun masih di bawah level akses dalam bangunan.

Untuk penggunaan material pada bangunan pengasapan ikan, penulis merekomendasikan sebagai berikut :

Tabel 5.1. Tabel Rekomendasi Material Bangunan Pengasapan Ikan (Analisa, 2016)

\begin{tabular}{|c|c|c|c|}
\hline No. & $\begin{array}{l}\text { Eleween } \\
\text { Reuang }\end{array}$ & Stabdar & Rekomendasi Material \\
\hline 1. & Lambii & 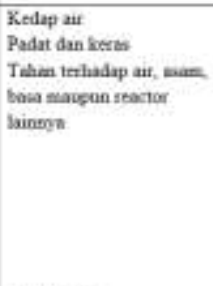 & 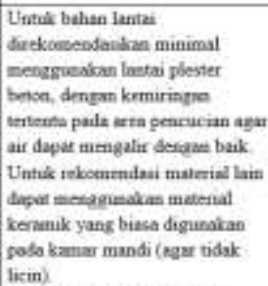 \\
\hline 2 & Dinding & 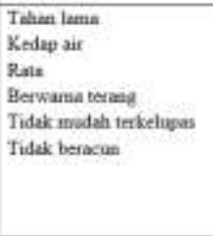 & 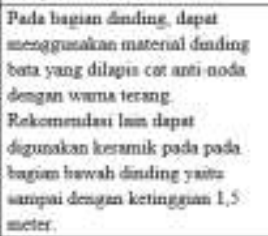 \\
\hline
\end{tabular}

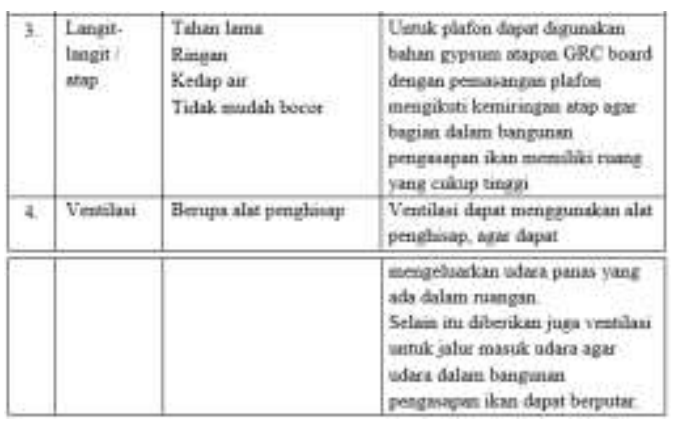

DAFTAR PUSTAKA

Ahyat, B. (2013). Kajian Permukiman Daerah Aliran Sungai Studi Kasus: Krueng Langsa. Sumatera Utara: USU Institutional Repository . Daldjoeni, N. (2003). Geografi Kota dan Desa. Bandung: P.T. Alumni.

Efendi, Y., \& Yusra. (2012). Pengendalian Mutu Hasil Perikanan. Padang: Bung Hatta University Press.

Harsritanto , Bangun IR (2016) A Review of Universal Design on Eldery House Designs Development, Modul vol 16 no. 2 p112-120

Kostof, S. K. (1991). The City Shaped: Urban Patterns and Meanings .

Masithoh. (2008). Pengelolaan Lingkungan pada Sentra Industri Rumah Tangga Pengasapan Ikan Bandarharjo Semarang. Tesis, 58.

Nastiti, D. (2006). Kajian Peningkatan Mutu Produk Ikan Manyung (Arius thalassinus) Panggang di Kota Semarang. Program Studi Magister Manajemen Sumberdaya Pantai. Program Pascasarjana Universitas Diponegoro.

Pemerintah Kota Semarang (2004, Juni 8). Rencana Detail Tata Ruang Kota Semarang Bagian Wilayah Kota III. Peraturan Daerah Kota Semarang Nomor 8 Tahun 2004. Semarang, Jawa Tengah.

Rahayu, R. D., Purwono, E. H., \& Sujudwijono, N. (2015). Perancangan Bangunan Industri Terasi di Tuban. Malang: Universitas Brawijaya.

Sanger, G. (2010). Oksidasi Lemak Ikan Tongkol (Auxfs Thazardl Asap Yang Direndam Dalam Larutan Ekstrak Daun Sirih). Pacific Journal, 870-873.

Sebayang, N. (2002). Penerapan Teknologi Pengasapan Ikan Bagi Masyarakat Nelayan. Pengabdian Kepada Masyarakat, 25-34.

Yusroni, N. (2009). Analisis Profit Margin Untuk Meningkatkan Nilai Tambah Pendapatan Antar Pengrajin Pengasapan Ikan Manyung, Ikan Tongkol Dan Ikan Pari Di Bandarharjo Semarang. Semarang: Fakultas Ekonomi Universitas Wahid Hasyim. Semarang. 